\title{
Accessory mitral valve tissue: What lies beneath
}

\author{
Sameh M. Said, MD, FACS
}

From the Department of Cardiovascular Surgery, Mayo Clinic, Rochester, Minn.

Disclosures: Author has nothing to disclose with regard to commercial support.

Received for publication March 24, 2018; accepted for publication March 27, 2018; available ahead of print May $1,2018$.

Address for reprints: Sameh M. Said, MD, FACS, Department of Cardiovascular Surgery, Mayo Clinic, 200 First St SW, Rochester, MN 55905 (E-mail: said.sameh@mayo.edu).

J Thorac Cardiovasc Surg 2018;156:780

$0022-5223 / \$ 36.00$

Copyright $(2018$ Published by Elsevier Inc. on behalf of The American Association for Thoracic Surgery

https://doi.org/10.1016/j.jtcvs.2018.03.116

Accessory mitral valve tissue (AMVT) is rare; however, it can be an important cause of left ventricular outflow tract obstruction (LVOTO). Presentations are similar to other conditions that cause LVOTO and may include dyspnea, chest pain, fatigue, or syncope. It is often diagnosed incidentally and may be associated with other congenital cardiac malformations. Echocardiography and especially 3-dimensional echocardiogram play a key role in diagnosis. The indications for intervention remain limited to symptomatic patients with LVOTO. ${ }^{1}$

In the current case reported by Laguna and colleagues ${ }^{2}$ in this issue of the Journal, the authors present a 48-year-old man who underwent resection of a subaortic membrane and later presented with exertional syncope and was found out to have AMVT, which led to complete LVOTO during systole. He underwent repeat operation with resection of this AMVT concomitant with mitral valve (MV) repair and with complete relief of LVOTO. The case represented a delayed diagnosis of AMVT despite the fact the patient underwent previous resection of subaortic membrane.

AMVT may represent a remnant of endocardial cushions that did not fuse with the anterior MV leaflet properly and remains in the left ventricular out flow tract. This anomaly has been classified by Prifti and colleagues ${ }^{3}$ into different types based on the insertion, mobility, and the relationship to the aortic valve and MV. The greatest challenge during surgery for AMVT is to define the anatomical relationship between the anterior MV leaflet and the AMVT, and resection has to be done with caution to avoid injury to the MV and subsequent incompetence. The presented patient underwent resection of subaortic membrane in his first operation, but his AMVT was not identified at that time. There was no

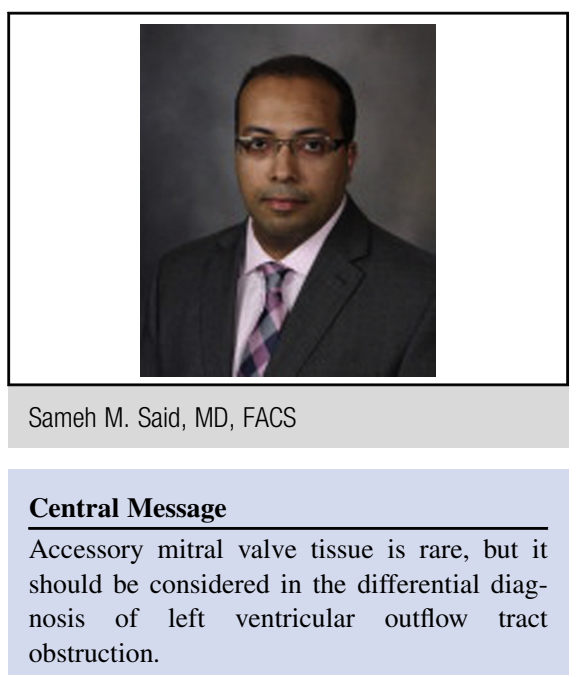

See Article page 777 .

description of the anatomical features for this membrane during the first surgery, but also this could represent AMVT type I as defined by Prifti and colleagues, which can point to incomplete resection of the AMVT during the first operation. This is not uncommon.

In conclusion, despite its rarity, AMVT should be always considered in the differential diagnosis of LVOTO, and surgery for LVOTO should include assessment of the left ventricular out flow tract and inspection of the other lesscommon etiologies such as AMVT, anomalous chordae, and abnormal papillary muscles.

\section{References}

1. Manganaro R, Zito C, Khandheria BK, Cusmà-Piccione M, Chiara Todaro M, Oreto G, et al. Accessory mitral valve tissue: an updated review of the literature. Eur Heart J Cardiovasc Imaging. 2014;15:489-97.

2. Laguna G, Blanco M, Carrascal Y. Subaortic stenosis by accessory mitral tissue: failure of embryonic positioning? J Thorac Cardiovasc Surg. 2018;156:777-9.

3. Prifti E, Frati G, Bonacchi M, Vanini V, Chauvaud S. Accessory mitral valve tissue causing left ventricular outflow tract obstruction: case reports and literature review. J Heart Valve Dis. 2001;10:774-8. 